\title{
The Role of the Elections Supervisory Agency to Contend Hoax and Hate Speech in the Course of 2019 Indonesian General Election ${ }^{*}$
}

\author{
Fritz Edward Siregar ${ }^{* *}$ \\ DOI: https://doi.org/10.22304/pjih.v7n2.a2
}

Submitted: April 13, 2020 | Accepted: June 29, 2020

\begin{abstract}
The Elections Supervisory Agency, in Indonesia known as Bawaslu (Badan Pengawas Pemilu), is the supervisor for all elections in Indonesia. The Agency has many roles, authorities, and obligations. One of their authorities is to oversee the activities of campaigns in various platforms, including the social media. The Agency has an authority to ensure and to keep the election participants not to violate campaign rules. They are obliged to ensure no misuse of social media, considering that the social media has been platforms to spread hoaxes and hate speeches-activities that can disrupt and undermine the ongoing democratic process. This study aims to explain the achievements of Bawaslu in carrying out the process of monitoring social media, the obstacles, the findings, the enforcements, and the importance of the role of state institutions. Prior to the prosecution, such as taking down media content, account deletion, or criminal prosecution, it is necessary to pay attention to the existing legal rules. This study performed analysis employing qualitative method with juridical-empirical approach. The data consisted of the spread of hoaxes and hate speeches that are spread on social media during the course of the 2019 Election stages.
\end{abstract}

Keyword: election supervision, freedom of expression, hoax and hate speech.

\section{Peran Badan Pengawas Pemilu Menangani Berita Bohong dan Ujaran Kebencian dalam Pemilu 2019}

\begin{abstract}
Abstrak
Dalam kedudukannya sebagai pengawas pemilu, Badan Pengawas Pemilu (Bawaslu) tidak sekadar berwenang untuk mengawasi pelaksanaan kampanye melalui media sosial oleh para peserta pemilu untuk tidak melanggar aturan kampanye. Bawaslu berkewajiban memastikan agar tidak ada penyalahgunaan media sosial dengan berita bohong (hoax) dan ujaran kebencian (hate speech), yang dapat menganggu dan merusak proses demokrasi yang berlangsung. Akan tetapi pengawasan di media sosial memiliki persoalan tersendiri karena dibutuhkan keseimbangan antara pembatasan kebebasan berbicara dan aturan mengenai ujaran kebencian. Artikel ini berusaha untuk menjelaskan, apa saja yang sudah dilakukan oleh Bawaslu dalam melakukan proses pengawasan di media sosial, hambatan
\end{abstract}

\section{PADJADJARAN Journal of Law Vol. 7 Number 2 Year 2020 [ISSN 2460-1543] [ISSN 2442-9325]}

This article has been published as a part of Bawaslu's Report on Evaluation Series of Conducting 2019 Simultaneous Elections.

** Member of Election Supervisory Board of The Republic of Indonesia; Lecturer of Indonesia Jentera School of Law, email: fritzedward@gmail.com 
yang dialami, temuan yang ditindak lanjutin dan pentingnya peran antar lembaga negara. Sebelum dilakukan proses penindakan baik penurunan konten, penghapusan akun serta proses pidana, perlunya memperhatikan aturan hukum yang ada. Analisa dalam tulisan ini ditulis berdasarkan kajian kualitatif dengan pendekatan yuridis-empiris dan penyebaran isu kebohongan dan ujaran kebencian yang ada di media sosial selama proses pemilu 2019 berlangsung.

Kata kunci: hoaks dan ujaran kebencian, kebebasan berbicara, pengawasan pemilu.

\section{A. Introduction}

Nowadays, people face new phenomena that change almost every aspect of human life. One of them is the development of information technology through internet. ${ }^{1}$ This condition leads to a new realm order, which is often referred to as a global village inhabited by netizens. One of the most widely used internet platforms is social media. Social media that are growing and attracting many people are, among others, Facebook, Instagram, Twitter, YouTube, WhatsApp, etc. Social media allows anyone to easily access information and communication and express their thoughts and opinions without time and space constraints.

Although this social media appears in the context of friendships, they also touch politics. In Ruben's critical view, the progress of digital communication will lead to a new spirit of democracy. ${ }^{2}$ The presence of social-media-based communication has made democratic landscape undergoing significant changes towards participatory democracy. The participation now includes horizontal participation of people in the process of joint decision-making. Hague and Loader refer to such democracy as 'digital democracy'. ${ }^{3}$ On behalf of democracy, anyone can freely express their thoughts and opinions in digital spaces.

The use of social media in various fields promises various facilities. However, it does not make social media, as an information technology system, free of problems. The social media also provides negative impacts since they also open up opportunities for the emergence of anti-social actions and new types of crimes. The facts may disturb both cyber community and state administrator since the negative effects may also affect security and public order. At this point, there is a contradictory condition. On one side, there is euphoria of freedom of expression on the Internet. On the other hand, there is tension between freedom of expression and security factors. ${ }^{4}$

1 Tim Lindsey (et.al), Hak kekayaan Intelektual Suatu Pengantar, Bandung: Asian Law Group Pty Ltd and Penerbit Alumni, 2006, p. 162.

2 Anthony G. Wilhelm, Demokrasi di Era Digital, Tantangan Kehidupan Politik di Ruang Cyber, Yogyakarta: Pustaka Pelajar, 2003, p. 87.

3 B. N. Hague and B. D. Loader, Digital Democracy: Discourse and the Decision Making in the Information Age, New York: Routledge, 1999, p. 6.

4 AJI Indonesia, Internet, Media Online, dan Demokrasi di Indonesia: Position Paper Aliansi Jurnalis Independen Indonesia Atas Persoalan Tata Kelola Internet di Indonesia, Jakarta: AJl Indonesia, 2013, p. 12. 
In Indonesia, the quinquennial political contestation (General Election) often involves various anti-social actions and crime acts. They are especially happened in the Presidential Election. The phenomena of the black campaign, spread of hoax, and hate speech, in fact, are a daily routine in the social media. Election is no longer an exciting democratic party. Instead, it has become a place to spread hatred and defamation in the public. As a result, people are polarized to the two poles clashing each other. In certain circumstances, the phenomena cause escalations of tensions that lead to disruption of state order and security. In this context, State, through governmental agencies, often take decisive action in the form of the internet restrictions by blocking, filtering, close watching, taking-down, throttling, and shutting down the internet and mobile service. In certain circumstances, state makes arrests.

The problem becomes interesting when the Government actions are linked to the citizens' freedom of expression on behalf of democracy. The freedom of expression is guaranteed by the Constitution. In this case, people may need to know the role of The Elections Supervisory Agency, in Indonesia known as Bawaslu (Badan Pengawas Pemilu). Bawaslu has many roles, authorities, and obligations. One of their authorities is to oversee the activities of campaigns in various platforms, including the social media. The Agency has an authority to ensure and to keep the election participants not to violate campaign rules. They are obliged to ensure no misuse of social media, considering that the social media has been platforms to spread hoaxes and hate speeches-activities that can disrupt and undermine the ongoing democratic process. In the 2019 General Election campaign stage, Bawaslu recommended blocking and deleting content on sites that included ethnic, religious, racial, and intergroup issues and social media accounts that spread false news, hate speech, or black campaigns. Until now, there have been at least around 7,000 accounts having hate speech contents and 120 social media accounts to be taken-down.

\section{B. Related Literature Review on Social Media Monitoring by the Government 1. Democracy and Freedom of Expression}

Democracy is a political order and an appropriate model of state management. Democracy provides space for citizens to express their thoughts freely. In Fishkin's notes, democracy enables citizens to get references to take part in determining public policies, through the availability of quality information. ${ }^{5}$ At this point, democracy is not interpreted merely as representative democracy, but it has differences based on the public expression. Habermas states that the democracy that has the root in the public sphere is called deliberative democracy. For Habermas, democracy must have a deliberative dimension. It means that every

J. S. Fishkin, When the People Speak: Deliberative Democracy \& Public Consultation, New York: Oxford University Press, 2009, p. 14. 
decision-making must be ratified first in public discourse. It was intended to legitimize the decision. ${ }^{6}$

The emergence of the idea of deliberative democracy cannot be separated from the communitarian thinking. Pierre \& Peters write, "In some ways, ideas about deliberative democracy comprise a subset of communitarian thinking. The basic idea of creating a locus for making decisions at a low level of aggregation appears compatible with communitarian thinking". The essential thing from the operation of deliberative democracy is the existence of involving the public in decision-making process through open debate and dialogue. ${ }^{7}$ In other words, the source of legitimacy is not determined by the will of individual but by consensus obtained through deliberation. Manin states, "... the source of legitimacy is not the predetermined will of individuals, but rather the process of its formation, that is, deliberation itself ${ }^{\prime} .{ }^{8}$ At this point, reciprocity is the main principle of deliberative democracy. State automatically no longer determines law and other policies in a comfortable splendid isolation, but the entire civil society play a significant influence in the formation process of making laws and political policies. ${ }^{9}$

The nature of deliberative democracy rooted in public space is correlated with civil liberties. According to Bealey, civil liberties include freedom of expression, freedom of press, freedom of assembly, and freedom of worship. ${ }^{10}$ In modern democracies, every citizen is guaranteed to express civil liberties without intimidation and threats. Freedom of expression is a fundamental human right that must be fulfilled and respected. It has even become a universal benchmark outlined in Universal Declaration of Human Rights, "Everyone has the right to freedom of opinion and expression; this right includes freedom to hold opinions without interference and to seek, receive and impart information and ideas through any media and regardless of frontiers."

Despite the implementation of the freedom of expression, there are still many threats. The threats may come from supreme coercive authority seeing it as a potential disruption to political hegemony. They can also come from fellow members of civil society. John Stuart Mill refers to the phenomenon "tyranny of the majority". However, democracy always provides space for citizens to express their rights freely, including participation in the process of making laws and public policies. However, it is important to maintain that citizen expression of civil liberties is very dependent on policies set by state.

6 This view is a critique of Rousseau's opinion that the source of legitimacy is public's will. Therefore, despite the process, a legal product that is declared as a public means that the product has been legitimized. See Wimmy Haliim, "Demokrasi Deliberatif Indonesia: Konsep Partisipasi Masyarakat dalam Membentuk Demokrasi dan Hukum yang Responsif", Jurnal Masyarakat Indonesia, Vol. 42, Issue 1, 2016, p. 21.

J. Pierre and B. G. Peters, Governance, Politics and the State, New York: St. Martin's Press, 2000, p. 150.

B. Manin, "On Legitimacy and Deliberation", Political Theory, Vol. 15, Issue 3, 1987, p. 351.

9 Fatkhurohman, "Mengukur Kesamaan Paham Demokrasi Deliberatif, Demokrasi Pancasila dan Demokrasi Konstitusional", Jurnal Konstitusi, Vol. 4, Issue 2, 2011, p. 43.

10 Maswadi Rauf (et.al), Indeks Demokrasi Indonesia 2010 Kebebasan yang Bertanggung Jawab dan Substansial: Sebuah Tantangan, Jakarta: Badan Pusat Statistik, 2012, p. 24. 


\section{Restrictions on the Use of Social Media}

In the current digital era, social media has provided a new platform of the development of democracy. Evans reveals that social media is often associated with freedom of information in democracy because it changes a person from a content reader to a content publisher. This phenomenon is a shift of broadcast mechanism. There are some fundamental elements of social media. First, social media involves different social channels; and online is the main channel. Second, social media changes from time to time and continues to grow. Third, social media is participatory since creative audience has the right to speak enabling them to comment. $^{11}$

Currently, social media is experiencing very significant developments, at both global and Indonesian levels. It is a complex social phenomenon covering the construction of social relations and production of communication and information. ${ }^{12}$ The phenomena are reflected in the definition of social media. Boyd and Ellison says, "...web-based Services that allow individuals to (1) construct a public or semi-public profile within a bounded system, (2) articulate a list of other users with whom they share a connection, and (3) view and traverse their list of connections and those made by others within the system."13

Social media is supported by the power of communication technology. It has become a space for the disseminations of opinions and discourses, space to gather and to organize the masses. Undoubtedly, social media has become an effective communication instrument to influence public opinion in democratic atmosphere. It is a consequence of state's positive obligations to promote and facilitate the right to freedom of expression.

Social media has a vital role in political process. The role is manifested in public participation. It also has become a new way for politicians to perform political communication. Political participation aims to influence policymaking process. Riley interprets conventional political participation as political engagement; it is " a set of rights and duties that involve formally organized civic and political activities (e.g., voting or joining a political party)". ${ }^{14}$ Diemer also refers to participation as "an engagement with traditional mechanisms in the....political system, such as voting in

11 Dave Evans, Social Media Marketing an Hour a Day, Canada: Wiley Publishing Inc, 2008, p. 34.

12 Athiqah Nur Alami, "Menakar Kekuatan Media Sosial Menjelang Pemilu 2014", Penelitian Politik LIPI Journal, Vol. 10, Issue 1, 2013, p. 86.

13 D. M. Boyd and N. B. Ellison, "Social Network Sites: Definition, History, and Scholarship", Journal of ComputerMediated Communication, Vol. 13, Issue I, 2007, p. 211.

14 C.E. Riley, C. Griffin, and Y. Morey, "The Case of 'Everyday Politics': Evaluating Neo-Tribal Theory as A Way to Understand Alternative Form of Political Participation, Using Electronic Dance Music Culture as An Example", Sociology Journal, Vol. 44, Issue 2, 2010, pp. 345-363. 
elections and joining political organizations. ${ }^{\prime 15}$ In this context, social media can be an alternative form of community participation in the era of globalization.

Another example, in the context of election, political party has treated social media as a means of campaigning to influence voters and to gain support and victory. The existence of social media allows political socialization or targeted campaigns with relatively low costs. In short, the use of social media in campaigns has been a keyword to build political communication networks to win political competitions. For Burke, the choice to use social media to build a strong political communication network to gain support is natural. Burke interprets this political communication as a systematic pattern governing relations between individuals and groups in the exchange of political information. The formation of a political communication network by using social media is a practical reason to foster participation that encourages contribution and feedback, as well as to eliminate distance between news sources and audiences strengthening discussion. ${ }^{16}$

Enli and Moe conclude that social media is a very effective and efficient medium for politicians to deliver messages in their campaigns. Social media can be a reciprocal relationship between politicians and voters. ${ }^{17}$ In addition, social media can be used to gain access to mainstream media. Campaigns delivered on social media are important source of information for mainstream media. ${ }^{18}$ Politicians who actively convey information on their social media are likely to get the voters' attention. ${ }^{19}$ Thus, the use of social media in campaigns has increased public participation in election.

Apart from its positive effects, the presence of social media in political campaigns also has the potential to be a destructive means. Black campaign, hoax, hate speech, rumour, bullying, defamation, and issues concerning ethnic, religious, racial, and intergroup are the dark sides of social media presence in politics. The dark sides of social media are more vibrant amid the low level of public literacy. In the 2019 General Election, Bawaslu received at least 610 reports of hoaxes on social media. Only 187 contents that have been reported to the social media administrators (such as Facebook, Twitter, Instagram, and Youtube) to be taken down. Bawaslu has requested assistance from the Ministry of Communication and Information Technology to impose sanctions on social media platforms that refuse to take down the content. For instance, based on Bawaslu's recommendation, the Ministry of Communication and Information Technology closed the

15 M. A. Diemer, “Fostering Marginalized Youths' Political Participation: Longitudinal Roles of Parental Political Socialization and Youth Sociopolitical Development", American Journal of Community Psychology, Vol. 9, Issue 1, 2012, p. 256.

16 Peter Burke, Sejarah Sosial Media, Jakarta: Penerbit Yayasan Obor Indonesia, 2000, p. 380.

17 Gunn Enli and Hallvard Moe, "Introduction to Special Issue: Social Media and Election Campaigns - Key Tendencies and Ways Forward", Information, Communication \& Society Journals, Vol. 16, Issue 5, 2013, p. 640.

18 M. Broesma and T. Graham, "Social Media as Beat, Tweet as News Sources during 2010 British and Dutch Elections", Journalism Practice Journal, Vol. 6, Issue 3, 2012, pp. 403-419.

19 Morten Skovsgaard and Arjen Van Dalen, Dodging The Gatekeepers?: Social Media in the Campaign Mix During the 2011 Danish Elections", Information, Communication \& Society Journals, Vol. 16, Issue 5, 2013, p. 742. 
site www.jurdil.org because the site was proven to violate the regulation of campaign and carrying out activities disturbing the Election phase based on the Law Number 7 of 2017 on General Elections. Even the Ministry of Communication and Information Technology restricted access to social media features and messaging services by slowing down video downloads and uploads. Such limitation is done gradually and temporarily to maintain state security.

The limitation of online media or social media is also practiced by the other states of the world. Brazil, for example, places restrictions on online content, especially during their general election. Iran, Cuba, and China remain the most restrictive states in the world in terms of internet freedom. The Governments of these states often block text messages and filter content, especially the ones that could potentially threaten the sustainability of the Government. Some states even arrest social media activist. ${ }^{20}$ Kelly (et.al) identify at least ten forms of restrictions on the use of the internet such as: ${ }^{21}$

a. blocking and filtering;

b. cyber-attacks against regime critics;

c. new laws and arrests based on online political, religious, or social speeches;

d. paid pro-government commentators to manipulate online discussions;

e. physical attacks and murder;

f. surveillance;

g. taking down and forcing deletion of content;

h. blocking of social media and other ICT platforms;

i. holding intermediaries liable; and

j. throttling or shutting down internet and mobile service.

The most common restrictions made by the government to limit the use of social media are blocking and filtering, surveillance, taking down and forcing content deletion, blocking of social media and other ICT platforms, and throttling or shutting down internet and mobile services. The decision to limit the use of social media in certain states is not only because of law and order but also to secure interests of authoritarian regime. However, restrictions on freedom of expression of online media users and social media are carried out mostly on the grounds of law enforcement, public order, and national security.

Further, it needs to be questioned whether law enforcement or public order and national security can be used as arguments to justify the restriction on the use of social media. These restrictive measures can be opposites of the freedom of expression. To answer such questions, this article starts with the statement that a democratic state provides public spaces that are "neutral" for every citizen to

20 Sanja Kelly, ect. (ed), Full Report Freedom on The Net 2013 A Global Assessment of Internet and Digital Media, New York: Freedom House, 2013, p. 3.

21 Ibid., pp. 3-7. 
express opinions, ideas, and even to criticize. The choice of democratic system naturally requires the freedom of expression.

Freedom of speech is an important element of democracy. It is a right of citizens, which includes freedom to express opinions, views, or ideas without any intervention, the right to seek, receive, and convey information through any media, regardless of regional boundaries. The freedom of expression can be in two ways: (1) the right to access, receive, and disseminate information; and (2) the right to express through any medium. ${ }^{22}$ According to Selian \& Melina, freedom of expression is an important element in the continuation of democracy and public participation in exercising their rights effectively in terms of both participation in the making of public policy and voting. If people do not have the freedom to express their opinions or to channel their aspirations, the level of democracy in a state is low. It may be a trait of an authoritarian government. ${ }^{23}$

\section{Relevant International Standards and Constitutional Stipulation}

The international human rights instruments specifically recognize human rights and freedoms, including freedom of expression that covers the freedom to express opinions. In the Universal Declaration of Human Rights (UDHR) adopted by the General Assembly of the United Nations (UN) in 1948, "Everyone has the right to freedom of ownership and expression; in this case includes freedom to hold an opinion without interference, and to seek, receive and submit information and opinion in any way and to properly view boundaries." ${ }^{\prime 24}$ However, freedom of expression is not absolute. The UDHR clearly says that freedom of expression does not mean unlimited freedom. Freedom of expression also has limits. Article 19 paragraph (2) of the UDHR states as follows.

"In the exercise of his rights and freedom, everyone shall be subject to such limitations as are determined by law solely for the purpose of securing due recognition and respect for the rights and freedoms of others and of meeting the just requirements of morality, public order, and the welfare in democratic society."

The Convention on the Elimination of All Forms of Racial Discrimination (CERD), adopted by the United Nations General Assembly in 1965, is the first international treaty to deal with expressions of hatred directly. ${ }^{25}$ Article 4 of the CERD identifies four different types of hate speech. They are (1) the spread of ideas based on racial superiority, (2) the dissemination of ideas based on racial hatred, (3) the incitement

\footnotetext{
ELSAM Team, Buku Saku Kebebasan Berekspresi di Internet, Jakarta: ELSAM, 2013, p. 17.

23 D. L. Selian and C. Melina, "Kebebasan Berekspresi di Era Demokrasi: Catatan Penegakan Hak Asasi Manusia", Lex Scientia Law Review, Vol. 2, Issue 2, 2018, p. 193.

24 United Nations, "The Universal Declaration of Human Rights", https://www.un.org/en/universal-declarationhuman-rights/, accessed on May 2020.

25 United Nations, "International Convention on the Elimination of All Forms of Racial Discrimination", https://www.ohchr.org/en/professionalinterest/pages/cerd.aspx, accessed on May 2020.
} 
to racial discrimination, and (4) incitement to racially motivated acts of violence. Article 4 specifically prohibits public authorities and institutions from promoting or inciting racial discrimination. It also requires that implementation steps should take into account the principles set out in the UDHR and the CERD Article 5, which provide equality before the law in enjoying a large number of rights, including freedom of expression. ${ }^{26}$ Article 4 of the CERD states as follows.

"States Parties condemn all propaganda and all organizations which are based on Ideas or theories of superiority of one race or group of persons of one color or ethnic origin, or which attempt to justify or promote racial hatred and discrimination in any form, and undertake to adopt immediate and positive measures designed to eradicate all incitement to, or acts of, such discrimination and, to this end, with due regard to the principles embodied in the Universal Declaration of Human Rights and the rights expressly set forth in article 5 of this Convention, inter alia:...."

The adoption of the International Covenant on Civil and Political Rights (ICCPR) in 1976 made the UN General Assembly to directly address incitement to hatred. Article 19 of the ICCPR affirms everyone's right to "opinion without interference". It further states that "everyone will have the right to freedom of expression, this right must include freedom to seek, receive, and provide information and ideas of all kinds, regardless of borders, whether orally, in writing or print, in the form of art, or through other media of his choice." At the same time, Article 19 recognizes the "special duties and responsibilities" that accompany the freedom of speech. In particular, freedom of speech may be subject to certain restrictions only if provided by law and required (1) to respect the rights or reputation of others; and (2) for the protection of national security or public order, or public health or moral. ${ }^{27}$ This is known as three-part tests of legality, legitimacy, and necessity. ${ }^{28}$

In addition, Article 20 of the ICCPR requires states to construct law that prohibits any incitement to hatred. ${ }^{29}$ Article 20 does not require states to prohibit all negative statements against national, racial, or religious groups nor does it prohibit the imposition of prohibitions as long as it is in accordance with Article 19 paragraph 3. In particular, it put the consequences dependent on incitement to discrimination, hostility, or violence. ${ }^{30}$ It inherently implies advocating national hatred, race, or religion, requiring that advocacy should involve incitement and that

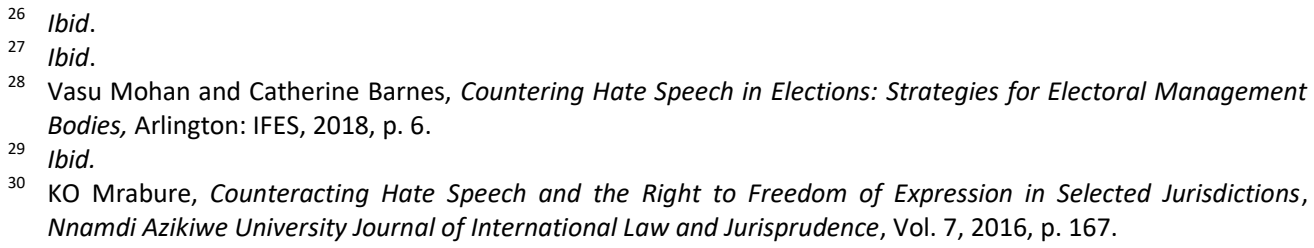


the incitement is related to discrimination, hostility, or violence. ${ }^{31}$ Some states have taken the view that only incitement intended to cause violence justifies restrictions on fundamental rights such as freedom of speech. ${ }^{32}$

Thus, everyone has the freedom of expression to express opinions, views, or ideas. Everyone is entitled to the rights to seek, receive, and convey information through any media, as long as it does not conflict with law. In this context, law becomes a determiner to the freedom of expression. Law here is defined as the legislation or the translation of the constitution, which is the resultant and the final statement of the will of the people. The purpose of the restriction is to secure the recognition and respect for the expression of the rights and freedoms of others. In addition, it is intended to meet the requirements of a just moral, public order, and welfare in a democratic society. In addition to the law, the freedom of expression is limited by the value of morality that lives and develops within society. The value of morality is the spirit that maintains freedom of expression. The value of morality guides citizens to behave.

The meaning of freedom of expression in the name of civil liberties is not in the free purpose as in Western states. Rather, it should be the freedom of expression with responsibility. In this sense, every citizen is free to express civil rights but is limited by positive law of state and moral values that live and blossom of political society. In other words, every citizen is free to express opinion in public spaces, including by using social media. However, the expression should be realized in ways that do not violate the principles and legal norms and do not conflict with moral values, politeness, and propriety that has been institutionalized in people's social life. The rights of access and use of the internet must be guaranteed for all and must not be subject to any restrictions. The exceptions is set by law to protect national security, public order, public health, and morals, and to protect the rights and freedoms of others. The idea has also become a standard for Indonesian citizens in the Constitution. Article 28J paragraph (2) of the 1945 Constitution reads as follows.

"In exercising their rights and freedoms, every person is obliged to submit to the limitations stipulated by law with the sole purpose of ensuring the recognition and respect for the rights and freedoms of others and to fulfil fair demands in accordance with moral considerations, religious values, security and public order in a democratic society".

\footnotetext{
31 Vitit Muntarbhorn, "Study on the Prohibition of Incitement to National, Racial, or Religious Hatred: Lessons from the Asia Pacific Region", https://www.ohchr.org/Documents/Issues/Expression/ICCPR/Bangkok/StudyBangkok_en.pdf, accessed on May 2020.

32 KO Mrabure, op.cit.
} 
Article 29J paragraph (2) of the 1945 Constitution provides restrictions on the freedom of expression. However, only law can perform these restrictions. It aims to assure recognition and respect for the rights and the freedoms of others and to meet fair demands in accordance with moral considerations, religious values, security, and public order in a democratic society. The restrictions are outlined in Article 28J, mostly even in all Articles from 28A to Article of the 1945 Constitution. Therefore, it needs to be emphasized that the human rights are outlined in the 1945 Constitution, but nothing is absolute. The ideas are also regulated in Article 73 of the Law on Human Rights, which governs restrictions on the expression of freedom of human rights.

At this point, the restrictions on the use of the internet or social media find justification. In the philosophical dimension, everyone can express opinions freely through social media. However, it must be remembered that the freedom of expression is also limited by the freedom of expression of others. Every citizen, in fact, has the right and the freedom of expression. To assure the protection and the respect for the rights of every citizen, state must be present with such restrictions of online or social media based on law. Therefore, government action cannot be interpreted as arbitrary or authoritarian government action. It is different when restrictive measures the use of online media or social media was performed by the government without a clear legal basis. It is in line with the teachings of the administration of law, in which various government actions have validity only when such actions are legally based on the governmental authority derived from laws. In other words, the justification for limiting the use of online or social media depends on mandate by law. Then, restrictive action can be valid government actions. It enables legal measurement.

\section{Campaign, Hoax, and Hate Speech in General Election}

\section{Rules for Campaigning on Social Media}

As explained above, Indonesia guarantees the freedom of expression of the people. However, that does not mean that everyone can act arbitrarily. People must be able to take responsibility for expressions in their contents. The fact is valid in many aspects, including campaigns. However, many people still make irresponsible content containing hoax and hate speech. Therefore, it was responded with a ban on campaigning on social media contained in Article 280 paragraph (1) letters $a, b$, c, and d of the Law Number 7 of 2017 on General Election (Election Law). The article explains that content is prohibited if it questions the Pancasila, the Preamble of the 1945 Constitution, and the Unitary Republic of Indonesia; conduct activities that endanger the integrity of the Unitary Republic of Indonesia; insult someone's religion, ethnicity, race, class, candidate and/or other Election Contestants; and incite individuals or society. There are sanctions for perpetrators. These sanctions are contained in Article 521 of the Election Law as follows. 
"Every perpetrator, participant, and/or member of campaign team who intentionally violates the prohibitions of the Election Campaign as referred to in Article 280 paragraph (1) letter $a$, letter $b$, letter $c$, letter $d$, letter $e$, letter $f$, letter $g$, letter $h$, letter $i$, or letter $j$ shall be sentenced to a maximum imprisonment of 2 (two) years and a maximum fine of Rp. 24,000,000 (twenty-four million rupiah)."

\section{The Authority}

Bawaslu has the authority to supervise every stage of election process, including campaign stage. They also have the authority to supervise every media used to campaign, including social media. Their authority to monitor social media is regulated in the Regulation of Elections Supervisory Agency Number 28 of 2018. The authority, among others, covers the monitoring of social media accounts, ones that either are or are not registered to the KPU.

For instances, Bawaslu monitored Instagram accounts @jokowi.amin and @indonesiaadilmakmur. Bawaslu consider these two official accounts did not contain hate speech or content that disrupt ethnic, religious, race, and intergroup elements. Bawaslu also monitored unauthorized accounts. Bawaslu often encountered hate speech contents in these unauthorized accounts. During the 2019 election process, Bawaslu reported that there were 127 social accounts spreading hoaxes. ${ }^{33}$ Bawaslu submitted the report to the Ministry of Communication and Information Technology or to the social media administrator so that these accounts are taken down.

To carry out the preventive function, Bawaslu has introduced the Election Vulnerability Index (IKP -Indeks Kerawanan Pemilu). The IKP is a series of research conducted as a basis to formulate policies, programs, and strategies throughout the election process. ${ }^{34}$ The IKP also contains the level of vulnerability of content that cover ethnic, religious, race, and intergroup elements, hate speech, and politicization in regencies and cities. The level of a vulnerability is based on the power relations. The 2019 IKP report mentions that 90 regencies and cities (17.5\%) are in the highly vulnerable category and 424 regencies and cities $(82.5 \%)$ are in highly vulnerable category.

Into the bargain, Bawaslu also has issued a Circular Letter to the Ministry of Communication and Information Technology and the social media administrators to remind them of the end of campaign period. The Circular Letter regulates that during election silence period and the Election Day, there should be no content on social media that includes campaign. Therefore, social media administrators have

33 Republika, "Bawaslu Laporkan 127 Akun Medsos Penyebar Hoaks", https://nasional.republika.co.id/berita/nasional/politik/pp17u3320/bawaslu-laporkan-127-akun-medsospenyebar-emhoaksem, accessed on May 2019.

34 Bawaslu RI, IKP 2019: Indeks Kerawanan Pemilu 2019 Pemilu Legislatif dan Pemilu Presiden, Jakarta: Bawaslu, 2018, p. iii. 
to take down such content. Such content spreader is a subject to sanctions stated in the Law Number 7 of 2017 on General Election. Based on the description above, it can be concluded that, in the supervision of the election process, campaigns on social media are the domain of Bawaslu supervision.

\section{Criminal Codes for Creators of Content and Spreaders of Disinformation}

Several sanctions for hoax and hate speech spreader are regulated in Indonesian laws. First, Article 14 of Law 1 of 1946 states that if someone who intentionally broadcasts false news, which causes a disruption in community, shall be sentenced to a maximum of ten years in prison. In the second paragraph, someone who distributes news that may cause confusion or duly thought, and the news is false, shall be sentenced to a maximum of three years in prison. In addition, someone who broadcasts uncertain news, excessive news, or incomplete news that causes a disruption shall be sentenced to two years in prison.

Spread of hoax and hate speech is also regulated in the Criminal Code, to be precise in Article 310 as follows.

"1. The person who intentionally harms someone's honor or reputation by charging him with a certain fact, with the obvious intent to give publicity thereof, shall, being guilty of slander, be punished by a maximum imprisonment of nine months or a maximum fine of three hundred rupiahs.

2. If this takes place by means of writings or portraits disseminated, openly demonstrated or put up, the principal shall, being guilty of libel, be punished with a maximum imprisonment of one year and four months or a maximum fine of three hundred rupiahs."

Further, Article 311 paragraph (1) of the Criminal Code also reads as follows.

"Any person who commits the crime of slander or libel in ease proof of the truth of the charged fact is permitted, shall, if he does not produce said proof and the charge has been made against his better judgment, being guilty of calumny, be punished by a maximum imprisonment of four years."

In addition, some laws are considered ambiguous but are often imposed on hoax or hate speech spreaders. One of them is the Law on the Information and Electronic Transactions. Article 28 paragraph (2) and Article 45A paragraph (2) of the Law read as follows.

"Article 28

(1) Any Person who knowingly and without authority disseminates false and misleading information resulting in consumer loss in Electronic Transactions.

(2) Any Person who knowingly and without authority disseminates 
information aimed at inflicting hatred or dissension on individuals and/or certain groups of community based on ethnic groups, religions, races, and inter-groups (SARA)."

\section{Article 45A paragraph (2)}

"Any Person who satisfies the elements as intended by Article 28 section (1) or section (2) shall be sentenced to imprisonment not exceeding 6 (six) years and/or a fine not exceeding Rp1,000,000,000,(one billion rupiah)."

Article 27 paragraph (3) of Law on the Information and Electronic Transactions prohibits anyone who intentionally disseminates or makes accessible electronicbased information that contains defamation.

"(3) Any Person who knowingly and without authority distributes and/or transmits and/or causes to be accessible Electronic Information and/or Electronic Records with contents of affronts and/or defamation."

Subsequently, Article 45 paragraph (3) of Law on the Information and Electronic Transactions mentions the sanction is imprisonment for a maximum of four years and/or a maximum fine of seven hundred and five million rupiahs.

\section{Hoax in Other States}

Election campaign provides fertile ground to spread hate speech. ${ }^{35}$ Parties who can influence hate speech are state officials, political parties, candidates, opinion makers, and community organizations. ${ }^{36}$ Furthermore, mass media, especially social media, has a significant impact on the spread of hate speech. ${ }^{37}$

Hate speech in election stages occurs in many states. One of them is Nigeria. Nigeria embraces democracy and faces hate speech challenge. ${ }^{38}$ Hate speech often arises during election stages in Nigeria through mass media. Hate speech always increase and develop during the election process causing violence and impedes political reconciliation after the vote. ${ }^{39}$ For example, in the post-1999 election, violence happened due to speech of hatred. Nevertheless, Nigeria already has an Election Law governing prohibition of hate speech as follows.

"A political campaign or slogan shall not be tainted with abusive language directly or indirectly likely to injure religious, ethnic, tribal, or

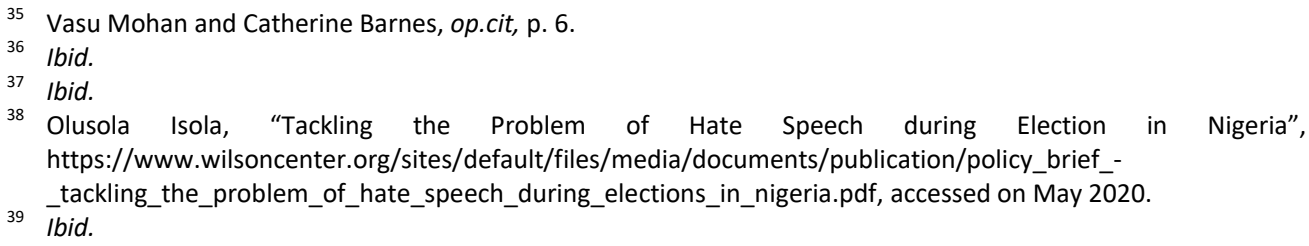


sectional feelings. Abusive, intemperate, slanderous, or base language or insinuations or innuendoes designed or likely to provoke violent reaction or emotions shall not be employed or used in political campaigns. " 40

In addition to Nigeria, Japan also has Public Offices Election Law. This law states that candidates cannot make hate speech against others via TV or radio. ${ }^{41}$ Almost the same in the United States, the US Supreme Court states that hate speech is not a right of freedom of expression as stated in the First Amendment. ${ }^{42}$ In their jurisprudence, the Supreme Court also states that demeaning ethnicity, race, gender, religion, age, disability, or similar thing is an expression of hatred. However, the Government must not limit citizens to offensive speech. Therefore, the jurisprudence protects someone who expresses hated thoughts. ${ }^{43}$

According to IFES data, Brazil is categorized partly free state in internet freedom. Bloggers or Information \& Communication Technologies (ICT) users are prohibited from writing political or social content. ${ }^{44}$ The violation may end up in imprisonment. This has happened when the Brazilian authorities arrested two Google directors for not taking down the prohibited content. ${ }^{45}$

\section{Hoax and Hate Speech Search Findings}

\section{Finding from Indonesia Indicator}

Bawaslu has staffs patrolling on social media. They also collaborate with Indonesia Indicator for monitoring. The Indonesia Indicator focused their monitoring on popular social media such as Twitter, Instagram, and Facebook. Based on pattern of hoax spread on social media, there are three crucial periods: (1) the campaign period (September 23, 2018, to April 13, 2019), (2) the election silence period (April 14 to 17, 2019), and (3) the announcement period (May, 21 to 22 2019).

During the campaign period, there were 43 issues discussed on social media. The main discussion during this period was the attacks on personal sides of two Presidential candidates: Jokowi and Prabowo. On Twitter, the top three issues discussed were the issues of Radical Islam behind Prabowo, Jokowi connection to the banned Indonesian Communist Party (PKI -Partai Komunis Indonesia), and proforeign Jokowi. The accumulation of conversations on Twitter reached the total of 806,472 conversations. Prabowo side was topics of $56 \%$ of the conversation on Twitter. On Facebook, the top three issues are the Radical Islam behind Prabowo, Jokowi and PKI, and Ratna Sarumpaet's hoax. The accumulated conversation on

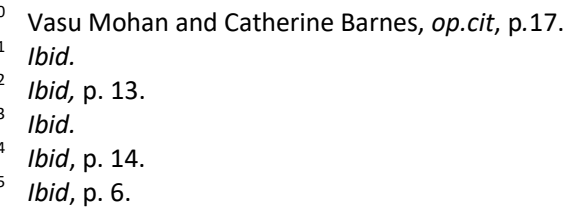


Facebook is 143,665 . The issue of the hoax tended to be aimed at Prabowo, up to $58 \%$. On Instagram, the spread of hoax issues to the two candidates is more balanced. The top three issues are Jokowi and PKI, pro-foreign Jokowi, and Prabowo of Chinese Descent. On social media, Jokowi and PKI was the top hoax narrative that appeared to be discussed. The attacks arose from gratuitous comments without any specific context. Various political uploads related to Jokowi will always be associated with Jokowi and PKI.

In the silence period, netizens developed 12 variants of issues. The intensity of hoax was dominant and spread in Twitter. There are 73,932 uploads on Twitter, 10,389 on Facebook, and 1,672 on Instagram. During this period, hoaxes are directed more to Jokowi side. The top three issues on Twitter and Instagram are the hacking on Abdul Somad's (a Muslim preacher supporting Prabowo) account, the quick count chaos, and the Jokowi's diversity hoax. On Facebook, it was not much different. The three issues that were often circulated are the hacking on Abdul Somad's account, the quick count chaos, and pro-caliphate Prabowo.

At the time of the announcement of the election results, the accumulation of conversation was obtained from six variants of issues. Twitter still occupied the first position as a medium of hoax spreading. There were 4,649 tweets on Twitter, 1,422 on Facebook, and 213 on Instagram. The hoaxes that spread during the announcement period were concentrated on the issue of the demonstration held in front of the Bawaslu Building. The threat of assassination against Jokowi became the top hoax issue. This issue was strengthened. It was driven by a viral video of a demonstrator who threatened to behead Jokowi.

\section{Finding from the Ministry of Communication and Information Technology}

During the election process, the Ministry of Communication and Information Technology also conducted monitoring and found 2457 hoaxes. This data was collected from August 2018 to June 2019. April 2019 was the month with most hoaxes, counting 501 issues. It was followed by March 2019 with 453 issues and May 2019 with 402 issues. Hoaxes were not only about the election but also many other things. There are 13 categories of hoaxes covering the topics of politics, health, government, defamation, crime, religion, natural disasters, myths, international, fraud, and education. Top three of them are politics with 813 issues, government with 328 issues, and health with 267 issues.

After the announcement, 245 hoaxes were discovered. There are three classifications of hoax in the range of May 20 to June 10, 2019: (1) the lie of May 22, provocation, and another hoax. These hoaxes were spread in Facebook, Instagram, Twitter, and YouTube. In total, the four media recorded 4595 Uniform Resource Locators spreading the hoaxes. According to the Ministry, Facebook is a medium with the most massive spreading of hoaxes. Combined with other social media, there are 1615 Uniform Resource Locators. 


\section{Stages of Reporting a Content}

In submission and evaluation of social media content, Bawaslu applies three steps before the content is reported to the administrator of social media or other followup is taken in accordance with statutory regulations. First, the content must meet the criteria of hoax or hate speech. Hoax is disinformation or news that is not correct. The way to determine the truth of a news is to clarify parties mentioned in the content. It makes collaboration with various parties is needed to check or to clarify fact of content.

Bawaslu conducted guided discussions with various stakeholders to define hoax and hate speech. ${ }^{46}$ Considering various international convention documents used in state administration, Bawaslu determines criteria to determine a content with hoax or hate speech as follows.

a. Identify the identity (character) that is attacked.

b. Identify the content and language used.

c. Measure the impact that may arise over the hate speech.

d. Prove the causality between the hate speech and the effect it causes.

e. Prove the intention of spreading hate speech.

f. Measure the extent of the spread of hate speech in the community and the influence of the spread of hate speech in the community.

Second, if the disinformation or hate speech element is fulfilled, the process of taking down the content is carried out or forwarded to the authorities based on the rules as explained above.

\section{E. Collaboration of Monitoring}

Bawaslu cannot monitor social media single-handedly. Bawaslu's involvement in social media monitoring began in January 2018 with the signing of a Memorandum of Action between Bawaslu, the Ministry of Communication and Information Technology, the General Elections Commision, and all social media administrators in Indonesia. The stakeholders agreed to make a declaration of commitments to (1) combat hoax, misleading information, and unanimous information offending ethnic, religious, race, and intergroup; (2) work together to increase literacy and education and countering hoax, misleading information, and unanimous information offending ethnic, religious, race, and intergroup; and (3) assure the readiness of social media platform to support the steps of the government and electoral agencies.

This declaration was signed on January 31, 2018 by all social media administrators. They are, among others, Google Indonesia, Facebook Indonesia, Twitter Indonesia, Telegram Indonesia, BBM Indonesia, LINE Indonesia, BIGO Live

46 International Foundation for Electoral Systems, "Countering Communal Incitement and Hate Speech in Indonesia", accessed on May 2020. https://www.ifes.org/news/countering-communal-incitement-and-hate-speech-indonesia, 
Indonesia, Live Me Indonesia, and METUBE. From the government side, the Ministry of Communication and Information Technology, the General Elections Commision signed the declaration. The MoA enables Bawaslu to conduct monitoring on social media and to have access to submit reports to the various social media platforms. ${ }^{47}$

Since the MoA was signed, Bawaslu has invited cooperation with other social media platforms, NGOs, and government agencies to carry out their supervisory functions. The following describes the collaborations between Bawaslu and other parties in 2018-2019.

Bawaslu collaborates with Google on social media monitoring. Bawaslu's, Google, and some other parties collaborated in a program called Pintar Memilih. This program contained two. First, the program made a website pintarmemilih.id. The website contains information related to elections. For example, it contains information about legislative candidates, how to vote overseas or domestically, political parties participating in the 2019 elections, the schedule of 2019 elections, page to report content containing hate speech and disinformation to Bawaslu. This website is a collaboration of Google, Perludem, Mafindo, Indonesia Youth IGF, Kok Bisa, the General elections Commission, and Bawaslu. ${ }^{48}$

The collaboration of Bawaslu, Google, Perludem, Mafindo, and Youth IGF Indonesia hold a roadshow 'Pintar Memilih' to eight campuses in Indonesia to campaign for the importance of young voters in the 2019 elections and to provide information related to disinformation and misinformation on social media during the 2019 Election. $^{49}$

Bawaslu also collaborated with Facebook to carry out five activities. First, they hold a roundtable discussion with the General elections Commission and the Ministry of Communication and Information Technology to equalize perceptions related to handling negative contents on social media during the 2019 Election. Second, they conducted the program 'Laju Digital', a digital literacy training in 15 major cities and regencies in Indonesia. In the program, Bawaslu involved Election Supervisory Agencies at the Provincial and regional levels as participants of the training. ${ }^{50}$ Third, they participated in the Facebook Summit, a seminar to improve the digital literacy of young people. In the event, Bawaslu also had the opportunity to discuss with WhatsApp officials related to the 2019 elections. Fourth, they hold Social Media Training. Facebook provided training to handle content for Provincial

47 Jakarta Globe, "Bawaslu, KPU and IT Ministry Join Forces to Fight Fake News Ahead of Regional Polls", https://jakartaglobe.id/news/bawaslu-kpu-ministry-join-forces-fight-fake-news-ahead-regional-polls/, accessed on May 2020.

48 See more on https://pintarmemilih.id/.

49 Mimbar Untan, "Indonesia Youth Internet Governance Forum (IGF) Selenggarakan Seminar Pintar Memilih", https://mimbaruntan.com/indonesia-youth-internet-governance-forum-igf-selenggarakan-seminar-pintarmemilih/, accessed on May 2020.

50 Kompas, "Laju Digital, Kampanye Facebook untuk Dorong Literasi Berinternet", https://regional.kompas.com/read/2018/09/13/09000081/laju-digital-kampanye-facebook-untuk-dorongliterasi-berinternet, accessed on May 2020. 
Bawaslu and public relations training for Bawaslu. Finally, Facebook helped Bawaslu to take down content that violates the Election Law, as well as taking down campaign ads that are still running during silence period.

Social media patrol conducted by Indonesia Indicator and Bawaslu shows that the spread of hoax issues is found massively on Twitter. Therefore, Bawaslu asked Twitter for help to take down content that violated the Election Law.

In addition to social media, Bawaslu also cooperates with several government agencies such as the Ministry of Communication and Information Technology, National Intelligent Agency, Indonesian National Army, Police of the Republic of Indonesia, Coordinating Ministry for Political, Legal, and Security Affairs, and the State Cyber and Cryptography Agency. In the collaboration between Bawaslu and the Ministry of Communication and Information Technology, there are four activities. First, the Ministry of Communication and Information Technology and Bawaslu hold a joint meeting with social media administrators to socialize the rules of the election silence period, especially the prohibition to display campaign advertisements during the period. Second, Bawaslu helped the Ministry of Communication and Information Technology to clarify several hoaxes related to the 2019 Election that was viral on social media. Finally, they blocked OC Websites. Bawaslu works closely with the Ministry of Communication and Information Technology to block jurdil2019.org, a website that misused the certification as Election Observers by displaying the results of a quick count.

In addition, Bawaslu cooperates with NGOs in carrying out its supervisory functions. They made a MoU and cooperation agreement with Mafindo (Masyarakat Anti Fitnah Indonesia --the Indonesian Anti-Defamation Society) to monitor social media during the 2019 Elections. Bawaslu also cooperates with Indonesia Indicator to patrols on social media. The results of the patrol are data of the spread of hoax issues during the election process. Bawaslu also issued a circular letter to conduct monitoring on social media during silence period to social media administrators and the Ministry of Communication and Information Technology:

(1) Circular Letter Number 0852/K.Bawaslu/PM.00.00/IV/2019;

(2) Circular Letter Number 0853/ K.Bawaslu/PM.00.00/IV/2019;

(3) Circular Letter Number 0122/K.Bawaslu/HK.01.00/IV/2019; and

(4) Circular Letter Number 0121/K.Bawaslu/HK.01.00/IV/2019

The circular contains request to social media administrators to take down content that included campaigns during silence periods and voting day.

As a result, during the 2019 elections stages, Bawaslu received 3,507 reports and followed up 174 of them. Administrators of social media took down 29 of them. In campaign advertising, Bawaslu has followed up on 147 campaign advertisements on social media. Administrators of social media took down 134 of them. Bawaslu also has clarified 13 misinformation issues. 


\section{F. Conclusion: The Future of Social Media Monitoring}

In carrying out the supervisory function of the 2019 elections, Bawaslu was not without obstacles. The spread of hoaxes and hate speeches in social media still remain, even after the General Election Commissions announced the result of presidential election on May 21, 2020. It is very challenging to supervise a wide range of social media and cooperate with other institutions is necessary. However, experts view that Bawaslu's efforts in monitor and combating hoax and hate speech deserve appreciation. ${ }^{51}$

This study has mentioned that there is no single authority in facing hoax and hate speech. People must understand the definition and the effects of hoax and hate speech. Hoax and hate speech creator need to be taken before law enforcement (taking down content and criminal law proceeding). To take down content, cooperation with social media administrators is very important. Different views about hoax and hate speech caused only small number of Bawaslu's takedown request, granted by the social media administrators.

The first challenge in combating hoax and hate speech is to obtain mutual understanding among stakeholders. The stakeholders need to sit together to make mutual perception in handling content of social media. The different view among stakeholders, such as state authorities and social media administrators, may lead to stagnant legal enforcement. The second challenge is public education on hoax and hate speech and consequences of distributing them. Democratic system gives space for citizens to have freedom of expression in any media. However, it requires understanding of the true meaning and the limitation of freedom of expression. People's ignorance may lead to lasting hoax and hate speech on social media. In addition, taking down content only puts a damper on the circulation of harmful content, but it does not eliminate negative content.

The role of Bawaslu in combating hoax and hate speech is limited only during election period. Other government institutions may step in and supervise. One of the important actors is the Ministry of Information and Information Technology. The Ministry has issued a draft of the Ministerial regulation on the Governance of the Implementation of Private Space of Electronic System. ${ }^{52}$ Articles 21 and 22 of the draft regulate the obligation of social media administrators to take down content 48 hours after a request submitted by public or state authorities. ${ }^{53}$ The failure to comply with the rule may lead to fine by the Ministry. This draft of

51 VOA Indonesia, "Pakar: Indonesia Bisa Jadi Panutan Dalam Mengatasi Tantangan di Era Hoax", https://www.voaindonesia.com/a/pakar-indonesia-bisa-jadi-panutan-dalam-mengatasi-tantangan-di-erahoax/5127348.html, accessed on May 2020.

52 Ministry of Communication and Information, "Siaran Pers No. 35/HM/KOMINFO/03/2020 tentang Konsultas Publik Rancangan Peraturan Menteri terkait Tata Kelola Penyelenggaraan Sistem Elektronik Lingkup Privat", https://www.kominfo.go.id/content/detail/24987/siaran-pers-no-35hmkominfo032020-tentang-konsultasipublik-rancangan-peraturan-menteri-terkait-tata-kelola-penyelenggaraan-sistem-elektronik-lingkupprivat/0/siaran_pers, accessed on May 2020.

53 Ibid. 
regulation may provide legal certainty in combating hoax and hate speech by imposing social media platforms to comply with a report filed by public and state authorities. However, this only able to settle one challenge, which is providing legal certainty about time to take down content. Nevertheless, the process that affects the definition of hoax and hate speech may need further studies.

\section{References}

\section{Books}

AJI Indonesia, Internet, Media Online, dan Demokrasi di Indonesia: Position Paper Aliansi Jurnalis Independen Indonesia Atas Persoalan Tata Kelola Internet di Indonesia, AJI Indonesia, Jakarta, 2013.

Burke, Peter, Sejarah Sosial Media, Penerbit Yayasan Obor Indonesia, Jakarta, 2000.

Evans, Dave, Social Media Marketing an Hour a Day, Wiley Publishing, Inc, Canada, 2008.

Fishkin, J. S, When the People Speak: Deliberative Democracy \& Public Consultation, Oxford University Press, New York, 2009.

Hague, B. N. and Loader, B. D., Digital Democracy: Discourse and the Decision Making in the Information Age, Routledge, New York, 1999.

Kelly, Sanja, (ed), Full Report Freedom on The Net 2013 A Global Assessment of Internet and Digital Media, Freedom House, New York, 2013.

Maswadi Rauf (et.al), Indeks Demokrasi Indonesia 2010 Kebebasan yang Bertanggung Jawab dan Substansial: Sebuah Tantangan, Badan Pusat Statistik, Jakarta, 2012.

Pierre, J. and B. G. Peters, Governance, Politics and the State, St. Martin's Press, New York, 2000.

Tim ELSAM, Buku Saku Kebebasan Berekspresi di Internet, ELSAM, Jakarta, 2013.

Tim Lindsey (et.al), Hak kekayaan Intelektual Suatu Pengantar, Asian Law Group Pty Ltd - Penerbit Alumni, Bandung, 2006.

Wilhelm, Anthony G, Demokrasi di Era Digital, Tantangan Kehidupan Politik di Ruang Cyber, Pustaka Pelajar, Yogyakarta, 2003.

\section{Other Documents}

Athiqah Nur Alami, "Menakar Kekuatan Media Sosial Menjelang Pemilu 2014", Penelitian Politik LIPI Journal, Vol. 10, Issue 1, 2013.

Boyd, D. M. and N. B. Ellison, "Social Network Sites: Definition, History, and Scholarship", Journal of Computer-Mediated Communication, Vol. 13, Issue 1, 2007.

Broesma, M. and T. Graham, "Social Media as Beat, Tweet as News Sources during 2010 British and Dutch Elections", Journalism Practice Journal, Vol. 6, Issue 3, 2012.

Riley, C. E., C. Grifin and Y. Morey, "The Case of 'Everyday Politics': Evaluating NeoTribal Theory as A Way to Understand Alternative Form of Political 
Participation, Using Electronic Dance Music Culture As An Example", Sociology Journal, Vol. 44, Issue 2, 2010.

Selian, D. L. and C. Melina, "Kebebasan Berekspresi di Era Demokrasi: Catatan Penegakan Hak Asasi Manusia", Lex Scientia Law Review, Vol. 2, Issue 2, 2018.

Diemer, M.A, "Fostering Marginalized Youths' Political Participation: Longitudinal Roles of Parental Political Socialization and Youth Sociopolitical Development", American Journal of Community Psychology, Vol. 9, Issue 1, 2012.

Enli, Gunn and Hallvard Moe, "Introduction to Special Issue: Social Media and Election Campaigns - Key Tendencies and Ways Forward", Information, Communication \& Society Journals, Vol. 16, Issue 5, 2013.

Fatkhurohman, "Mengukur Kesamaan Paham Demokrasi Deliberatif, Demokrasi Pancasila dan Demokrasi Konstitusional", Jurnal Konstitusi, Vol. 4, Issue 2, 2011. International Foundation for Electoral Systems, "Countering Communal Incitement and Hate Speech in Indonesia", https://www.ifes.org/news/counteringcommunal-incitement-and-hate-speech-indonesia.

Isola, Olusola, "Tackling the Problem of Hate Speech during Election in Nigeria", https://www.wilsoncenter.org/sites/default/files/media/documents/publicatio n/policy_brief_tackling_the_problem_of_hate_speech_during_elections_in_nig eria.pdf.

Jakarta Globe, "Bawaslu, KPU and IT Ministry Join Forces to Fight Fake News Ahead of Regional Polls", https://jakartaglobe.id/news/bawaslu-kpu-ministry-joinforces-fight-fake-news-ahead-regional-polls/.

Kompas, "Laju Digital, Kampanye Facebook untuk Dorong Literasi Berinternet", https://regional.kompas.com/read/2018/09/13/09000081/laju-digitalkampanye-facebook-untuk-dorong-literasi-berinternet.

Manin, B., "On Legitimacy and Deliberation", Political Theory, Vol. 15, Issue 3, 1987. Mimbar Untan, "Indonesia Youth Internet Governance Forum (IGF) Selenggarakan Seminar Pintar Memilih", https://mimbaruntan.com/indonesia-youth-internetgovernance-forum-igf-selenggarakan-seminar-pintar-memilih/.

Ministry of Communication and Information Technology, "Siaran Pers No. 35/HM/KOMINFO/03/2020 tentang Konsultas Publik Rancangan Peraturan Menteri terkait Tata Kelola Penyelenggaraan Sistem Elektronik Lingkup Privat", https://www.kominfo.go.id/content/detail/24987/siaran-pers-no-

$35 \mathrm{hmkominfo032020-tentang-konsultasi-publik-rancangan-peraturan-menteri-}$ terkait-tata-kelola-penyelenggaraan-sistem-elektronik-lingkupprivat/0/siaran_pers.

Muntarbhorn, Vitit, "Study on the Prohibition of Incitement to National, Racial, or Religious Hatred: Lessons from the Asia Pacific Region", https://www.ohchr.org/Documents/Issues/Expression/ICCPR/Bangkok/StudyBa ngkok_en.pdf. 
Republika, "Bawaslu Laporkan 127 Akun Medsos Penyebar Hoaks", https://nasional.republika.co.id/berita/nasional/politik/pp17u3320/bawaslulaporkan-127-akun-medsos-penyebar-emhoaksem.

Skovsgaard, Morten and Arjen van Dalen, "Dodging The Gatekeepers?: Social Media in the Campaign Mix During the 2011 Danish Elections", Information, Communication \& Society Journals, Vol. 16, Issue 5, 2013.

United Nations, "The Universal Declaration of Human Rights", https://www.un.org/en/universal-declaration-human-rights/. , "International Convention on the Elimination of All Forms of

Racial

Discrimination", https://www.ohchr.org/en/professionalinterest/pages/cerd.aspx.

VOA Indonesia, "Pakar: Indonesia Bisa Jadi Panutan Dalam Mengatasi Tantangan di Era Hoax", https://www.voaindonesia.com/a/pakar-indonesia-bisa-jadipanutan-dalam-mengatasi-tantangan-di-era-hoax/5127348.html.

Wimmy Haliim, "Demokrasi Deliberatif Indonesia: Konsep Partisipasi Masyarakat Dalam Membentuk Demokrasi dan Hukum yang Responsif", Jurnal Masyarakat Indonesia, Vol. 42, Issue 1, 2016. 